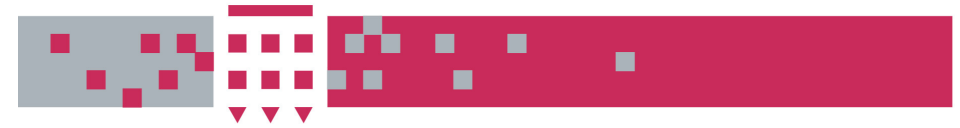

\title{
WestminsterResearch
}

http://www.wmin.ac.uk/westminsterresearch

\section{Managing the transition to work: the role of the planning network in British town planning education.}

\author{
Nick Bailey \\ Helen Walker \\ School of Architecture and the Built Environment
}

This is an electronic version of an article published in Planning Practice \& Research, 16(1), pp. 71-78, February 2001. Planning Practice \& Research is available online at:

http://www.journalsonline.tandf.co.uk/openurl.asp?genre=article\&issn=0269$\underline{7459 \text { \& volume }=16 \text { \&issue }=1 \& \text { spage }=71}$

The WestminsterResearch online digital archive at the University of Westminster aims to make the research output of the University available to a wider audience. Copyright and Moral Rights remain with the authors and/or copyright owners. Users are permitted to download and/or print one copy for non-commercial private study or research. Further distribution and any use of material from within this archive for profit-making enterprises or for commercial gain is strictly forbidden.

Whilst further distribution of specific materials from within this archive is forbidden, you may freely distribute the URL of WestminsterResearch. (http://www.wmin.ac.uk/westminsterresearch).

In case of abuse or copyright appearing without permission e-mail wattsn@wmin.ac.uk. 


\section{Managing the Transition to Work: The Role of the Planning Network in British Town Planning Education.}

Authors: Nick Bailey and Helen Walker (all enquiries to baileyn@wmin.ac.uk)

Published in Planning Practice and Research, 16(1) pp.71-78 2001.

The development of town planning education in the United Kingdom can be traced back over at least sixty years and has always enjoyed a close relationship with practitioners, employers and the professional body, the Royal Town Planning Institute (RTPI). In order to ensure an intake of sufficient quality to a growing profession, the Institute offered its own exams until the 1980s and then initiated the current system of accrediting both undergraduate and postgraduate programmes of study. This system of accreditation emphasises the importance of relevant knowledge, skills and values as well as core and specialised studies.

The vocational nature of town planning requires that graduates have the breadth of understanding as well as the practical skills in order to practice effectively. Thus accredited courses have over time developed strong links with employers and practitioners. Rapid developments in the scope and range of planning, and the skills needed to work in it, have reflected changes in public policy and growing number of agencies concerned with the built environment. The system of regular quinquennial visits to accredit courses has helped ensure that this acceptance of change has become part of the culture of planning schools. 
Nick Bailey and Helen Walker, School of the Built Environment, University of Westminster, 35 Marylebone Road, London NW1 5LS, UK. Email: baileyn@wmin.ac.uk or walkerh@wmin.ac.uk.

The trends in planning practice have been matched by similar developments in higher education. With the rapid expansion of higher education has come a shift from acquiring knowledge for its own sake to a growing concern to promote employability, the acquisition of skills and the concept of lifelong learning.

This article sets out to describe the role and evolution of the Planning Network, which since 1994 has explored the relationship between higher education and professional practice. In particular, it has examined how a reciprocal relationship can be developed between planning schools and the world of practice so that graduates are fully prepared for the transition to work.

From the outset, the Network took the view that the universities had a wider educative role than simply training graduates to be expert planners. As Grant notes in his perceptive paper prepared on behalf of the Institute:

It is the duty of universities to educate their students, not to produce fullytrained planners, and not to provide free training for the professions. It is their primary duty to enhance the intellectual and reflective capacity of their students, to develop their analytical and critical skills and to develop their capacity for further development. As the members' survey demonstrates, employment in planning is no more secure than any other white collar job, and new recruits therefore need to have the intellectual agility and transferable skills to provide them with alternatives for the future (Grant 1999: 7).

However, as well as developing students' intellectual and critical faculties, planning schools have a duty to assist students in acquiring the range of transferable and specific skills which will be of most value to them in their future careers (whether in planning posts or not). Much of the work of the Network has focused on the latter set 
of issues, whilst not forgetting the former. This broadly reflects the priorities of the funding body in the early 1990s - a concern that in general graduates should be better prepared for employment.

The work of the Network has evolved in three main phases. The outcomes and methods of dissemination are discussed and the Network's impact on a variety of stakeholders is assessed. Because of limitations of time and funding, the discussion centres on current developments in higher education and professional planning practice in the United Kingdom. The authors would be very interested in hearing about similar debates in other countries.

\section{The Origins of the Network}

The origins of the Network owe as much to developments in higher education as to changes taking place in the planning profession. From the 1980s successive governments were concerned to promote change in universities and polytechnics to ensure that graduates emerged with the capabilities to participate in the rapidly changing national economy. Enterprise in Higher Education (EHE) was a funding programme sponsored by the Department for Education and Employment (DfEE) to facilitate curriculum development, employer involvement and organisational change. About $£ 1 \mathrm{~m}$ was invested in 56 higher education institutions in order to make higher education more relevant to the world of work. The outcomes of the EHE initiative are fully discussed by Hawkins and Winter (1997). After an exhaustive review of higher education, the Dearing Report (1997) provided a vision for the next 20 years whereby participation rates could be increased while quality standards would be maintained. In order to establish a learning society, Dearing argued that higher education needed to 
become more responsive to the needs of both students and of clients such as employers. The Government reinforced this commitment to lifelong learning in a consultation paper, The Learning Age (DfEE 1998).

In 1994 the DfEE announced a new initiative to promote collaboration between subject specialists in UK universities, together with relevant employers and professional organisations. Funding for specific programmes of activities would be awarded on a competitive basis. The intention was that the resources be used to promote communication, electronically as well as through research and conferences, both within higher education and with relevant professional and employer groups. These were designated Discipline Networks. The rationale behind the programme was 'to help discipline based groups in higher education to work together'. Their focus was to be:

'helping higher education and employers to understand each other better; and helping academic staff to develop ways of making their students more employable' (McNair 1998).

The network in town planning was one of 24 successful bids in the first round in 1995 and funding was subsequently extended for a further year. The initial bid involved planning schools in Heriot-Watt, Oxford Brookes, West of England and Westminster Universities, together with the RTPI and planning consultants Tibbalds Monro. Membership was subsequently extended to include Aberdeen University, the Association of Consultant Planners, the County Planning Officers' Society and the National Council for Housing and Planning. 
In the early period, the Network was careful to avoid duplicating the work of the planning schools, and the RTPI in particular. However, there were a number of issues concerning the transition to work which members felt deserved further research and discussion. There was a strong feeling amongst planning schools that, although they individually had well established links with local practitioners, there was a need for a national debate about education and practice that might lead to improvements in course curricula, teaching methods and innovative practice in work-based learning. In the process, a wider range of employers of future planning graduates might be actively and directly involved in the educational process. The Education for Planning Association had performed a similar function in relation to teaching in planning schools until its demise in the late 1980s, but had not directly involved practitioners.

Thus the Network saw its role as developing issues of common concern among those involved in teaching, practice and representing the planning profession. It was particularly concerned that planning schools were not always aware of national, as opposed to local or regional, trends in professional practice. It was also aware that channels of communication between planning schools about teaching and learning were often partial and restricted. In addition, economies in higher education meant that resources for attending conferences, carrying out research into educational issues, and exchanging good practice were extremely limited. The key questions to be addressed were: What are employers' perceptions of the quality of graduates? How is the practice of planning changing and are these changes prompting the need for new educational approaches? How can the commitment and resources of all the stakeholders in the educational process be harnessed to ease the transfer of high 
quality graduates into professional practice? Where do responsibilities lie for promoting lifelong learning?

The Network was therefore funded for two years to pursue a predetermined set of objectives with a limited budget but with a strong sense of common interest and enthusiasm between the members. By involving academics, practitioners and professional bodies with similar interests and a commitment to change, much was achieved in a limited period of time. A further opportunity for funding arose when the DfEE issued a prospectus of topics in 1997. The Network bid successfully for a third phase of funding beginning in May 1998 in order to investigate innovation and creativity in the curriculum.

The evolution of the Planning Network can best be described as both strategic and pragmatic. The Network has been strategic in the sense that the focus during the period of funding was on the relationship between teaching and learning and the transition to practice. It has been pragmatic in that it sought out opportunities for funding which would facilitate this broad agenda. Moreover, the Network developed new working methods designed to promote genuine mutual learning and collaboration. There have been no designated officers and meetings and conferences have taken place in a variety of locations. Responsibility for chairing meetings and conferences has fallen either to the host organisation or to an invited guest, for example, an employer from the public or private sectors. The Network was inclusive in that specialists from the worlds of education or planning practice were invited to participate. Dissemination through reports, articles and conferences was often backed up by presentations to key target groups. 


\section{Key Outputs}

The work of the Network falls into three main phases representing the three years of funding. In each case, clear objectives were established in the funding proposal and these formed the basis for planning research, events and dissemination over each twelve month period. A detailed report was published at the end of each funding period which was then distributed widely to the 24 planning schools in the UK, practitioners and through the RTPI.

\section{Employer Perceptions of Graduate Skills}

In the first year (1994-95) four key objectives were specified which related to issues of the changing knowledge and skills base of town planning, the perceptions of employers as to how their requirements for graduates are changing, and the response of planning courses in providing teaching programmes that integrate both vocational and educational objectives. In 1995 the four member planning schools carried out a survey of a sample of employers to discover how far the expectations of those actively recruiting new graduates were being matched by the knowledge and skills presented by applicants. The findings are discussed in full in two Network reports (Discipline Network in Town Planning1996a, 1996b).

The overriding conclusions to emerge from the research were that planning education at undergraduate and postgraduate levels was generally providing the range of skills and knowledge sought by employers, but that some changes were needed. At least partly because of the growing competition for posts, employers reported broad satisfaction with the quality of applicants. Many, however, felt that an additional 
emphasis was needed in some aspects of the curriculum because of changes in the policy and professional environment. One of the most interesting conclusions to emerge was that, with a few exceptions, employers were not looking for highly trained specialists in a particular aspect of planning. Instead, they emphasised the need for a balance between a broad understanding of the planning process and an appropriate range of personal skills. Skills particularly valued by employers included: oral and written communication; interpersonal skills; team working; customer orientation; time management; facilitating meetings; negotiation; and creative and lateral thinking. A typical response was: '...the ability to communicate effectively is considered more important than academic achievement and technical skills' (Discipline Network in Town Planning 1996b: 14).

In addition, respondents felt that greater emphasis should be given to those aspects of the curriculum covering the financing of development; environmental sustainability; the impact of the European Union and the need for a second language; and a knowledge of the customer-orientated culture in service delivery. There was also evidence that employers were increasingly selecting graduates with work experience, whether obtained through a year out, a placement or working in a planning office during vacations.

Thus the general message to come across from employers was that planning education produced graduates with a reasonable skill and knowledge base but that those with good personal skills, work experience, and a knowledge of development finance and the new management philosophies would have a definite advantage. One respondent went so far as to suggest: 'There is no longer an expectation of a job for life - this is 
now the case in local government as well. There is also more stress, longer hours and a bigger commitment required. Planning schools should be preparing their graduates for these changes' (Discipline Network in Town Planning 1996b: 16).

A number of respondents were critical of the weakness of some applicants in selection, presentation and interview skills. Whilst some employers, such as county councils, require those with specialist skills, most of the other categories were looking for the good generalist who could work as part of a team, communicate and negotiate effectively, as well as bringing creativity and imagination to problem-solving. At a conference for academics and practitioners in 1995, Andy Karski (a planning consultant) set out his view of the key attributes and qualities of the ideal planning graduate, here reproduced in Box 1.

\section{Box 1: Attributes and Qualities of the Ideal Planning Graduate:}

- A good understanding of planning knowledge, skills and values

- A capacity to work hard and learn fast

- An ability to acquire new knowledge and skills and to keep them up to date

- An ability to work hard alone and as part of a team

- An ability to work within a budget and programme constraints

- Resourcefulness; entrepreneurship; commitment

- Excellent interpersonal and communication skills

- A sense of humour and resilience

- An ability to make decisions and judgments and devise long-term strategies

- A marketable specialism based on qualifications and experience 
Source: Andy Karski, Tibbalds Monro, from the Network Conference 1995 in Bailey 1998.

Work-Based Learning

In the second period of funding (1996-97) the Network pursued the theme of linkage between higher education and professional practice by exploring those contexts where employers and potential graduates were most closely related in project work, sandwich years and placements. This focus on work-based learning also coincided with a major national study of the potential advantages of this mode of learning (Brennan \& Little 1996). The end product was a good practice guide which itemised the range of approaches adopted in planning schools (Higgins, Simpson et al., 1997). The main objectives for the year were:

- To provide an up-to-date survey of the various types of work-based learning provided by each of the schools offering RTPI-accredited courses in Britain and Ireland, identifying trends or likely changes;

- To analyse the processes and outcomes involved in work-based learning from the point of view of students, employers/practitioners and educators, evaluating any discrepancies in perceptions that may exist and provide good practice advice;

- To publicise the potential benefits of work-based learning;

- To share information and experience about work-based learning in order to better inform students; existing and prospective employers; the RTPI; and planning schools. 
The methodology employed involved carrying out three surveys of planning schools, a sample of current students in ten planning schools and structured interviews with employers with immediate experience of offering student placements. In addition, two conferences were arranged to debate issues relating to work-based learning from the points of view of academics, recently qualified students in their first planning post and employers.

The final report drew attention to the wide range of benefits arising from work-based learning to all concerned. It also sets out the ways in which 22 planning schools have successfully integrated innovative approaches to work-based learning in their course structures. For the purposes of the project work-based learning was defined as including: a sandwich year; placements; live projects; career development modules; and portfolios.

From the student point of view, the survey discovered that work-based learning enabled students to experience 'real' planning which deepened their understanding of both theory and practice. It also reinforced the importance of knowledge and technical skills while enabling them to explore the organisational and management dimensions of planning. Employers, on the other hand, reported that the presence of students challenged assumptions and working practices, stimulated other employees and often added value and enabled new projects to be undertaken. Planning schools welcomed the additional contact with employers and the local community which kept them in touch with current practice. Students often returned to their studies with greater maturity and understanding, particularly of the theoretical elements of the syllabus. 


\section{Innovation and Creativity in Planning}

In the third period of funding (1998-99) the Network successfully bid for funding to investigate innovation and creativity in the curriculum. As in previous years, the Network commissioned research studies and ran a series of conferences before presenting the main findings in a report (Bailey et al., 1999). The main objectives of the study were:

- To carry out a literature review into meanings, definition and usage of the terms innovation and creativity in relation to higher education and professional practice.

- To survey 50 practitioner organisations with 20 follow-up interviews to determine how employers perceive the meaning and importance of innovation and creativity and to discover how it is enhanced in the workplace.

- To survey 108 undergraduate and postgraduate students in five planning schools in order to find out how far and to what extent creativity was encouraged in their courses.

- To survey module leaders in 23 planning schools who teach two core areas of planning (urban design; development control/planning law) to discover how far creativity is an explicit learning objective and how it is assessed.

- To run a major conference on the topic with contributions on creativity in professional practice and workshops on how it is best integrated in the curriculum. 
- To produce a report, disseminate findings and to generate a debate between stakeholders in the planning profession.

The project produced a great deal of evidence about the growing importance of creativity in higher education, amongst employers and in society at large - not least in the Government's recent initiative to promote 'creative industries'. The Network took the view that creativity often refers to the intellectual process of discovery, recombining existing ideas or simply asking new questions and that it can be applied to creating new products and to redefining processes. Whilst in the past creativity has often been related to individual personality traits, it is now increasingly seen as an inherently human capability which can be enhanced through social and organisational processes. Successful development of the capability often comes through social interaction between teacher and learner, trust, confidence building, and risk-taking in a supportive environment. In this way the student can be encouraged to develop the skills of the 'reflective practitioner' (Higgins \& Morgan 2000).

The survey of employers found that they rarely include any reference to creativity either in mission statements or in the recruitment of staff and tend to define the term as flexibility, problem-solving or adding value in terms of business development or service delivery. Some employers use internal management systems to promote teamworking, staff development and value creativity in staff appraisal and promotions. In general, employers felt that more could be done to promote creativity in higher education through short projects, client-led projects, role-playing and work experience. They felt creativity was particularly relevant in urban design, regeneration and policy development. Creativity is particularly valued in the private sector because 
it delivers 'added value' to the client and thus to the consultancy itself. In the public sector it is also seen as important because it promotes the 'enabling' role of the organisation.

Many examples of good practice in the teaching of urban design and development control were identified in planning schools. Urban designers felt that creativity was integral to the whole subject, whilst those teaching development control stressed the importance of fostering a creative approach to planning procedures. A minority of planning law lecturers felt that their task was to teach the law rather than attempt creative approaches before a basic understanding had been implanted. Lecturers noted that institutional barriers often had a negative effect on encouraging creativity; the lack of time or space in the curriculum, pressures to increase student numbers, inadequate studios and budgets were all mentioned.

A survey of students completing undergraduate and postgraduate planning courses in four universities sought their views on creativity in the curriculum. Some cited groupbased project work using actual cases, sites and issues as being important. Many welcomed the opportunity to develop their own solutions to real planning issues. Others identified making linkages, negotiation, lateral thinking, brainstorming and communication as important in developing their confidence to be creative. Visiting speakers and study visits introduced opportunities to learn about creative solutions and provided role models which aided the learning process.

The report drew a number of conclusions and made a wide range of recommendations to employers, planning schools and professional institutions. Whilst innovation and 
creativity are of growing importance in the context of changes in the economy, they are difficult to define absolutely and cannot be directly taught in higher education. They are best conceived of as capabilities which can be fostered in individual and group learning through explicit learning outcomes, creating time and freedom for experimentation in the curriculum, within a supportive and positive learning environment. The report concluded that planning schools should aim to produce graduates who are both creative and reflective practitioners.

Employers and practitioners should encourage their staff to become 'creative practitioners' through staff development, increased autonomy and by becoming learning organisations. There are also mutual benefits to be gained by working closely with planning schools and by facilitating work experience. Closer collaboration between all stakeholders helps to ensure that all those with an interest in higher education and vocational training develop a commitment to lifelong learning and understand the individual contributions they can make to maintaining a highly motivated and appropriately skilled workforce.

\section{Conclusions}

This article has set out to demonstrate the ways in which the Planning Network, since its inception in 1995, pursued a number of linked themes addressing the relationship between higher education in planning and professional practice. The Network emerged in a period when both higher education and planning itself were both undergoing rapid change. Indeed, funding largely became available because Government itself was committed to a similar agenda of promoting employability, employer involvement and lifelong learning. 
In retrospect, town planning as a vocational subject linked to a career pathway has many advantages in adapting to the new agenda for higher education. The process of accreditation by the Institute ensures that courses are up-to-date and that strong links with practice are developed. For example, most planning schools have practice panels which meet regularly with academics to advise on developments in professional practice. In addition, practitioners contribute in a variety of capacities, such as external examiners, sitting on validation panels, teaching and devising and contributing to project work.

The Network has drawn on these existing strengths but has also successfully utilised additional funding to carry out surveys and research, produce publications, run conferences and to generate a debate which enables good practice to be identified and widely shared. Dissemination has been extended to the planning schools and a variety of professional audiences in the UK and in Europe. The Royal Town Planning Institute has been a major contributor to the debate and has encouraged presentations to members of the Accreditation Panel at its annual meeting. Presentations to conferences of the Association of European Schools of Planning and other European planning organisations have extended knowledge of the work of the Network to a much wider audience.

In conclusion, thanks to a series of funding programmes available from the British Government's education department, the Network has successfully provided a forum for a much-needed review of the links between planning education and employment within a growing national debate about the purpose and direction of higher education. 
The cumulative value of the Network's output has helped portray planning education as rigorous and critical, in that it has explored the preparation student receive in their planning education before transferring into the world of practice. Planning education involves much more than the simple acquisition of a convenient range of off-the-peg skills. The Network has at least established a forum where practitioners and academics can begin the debate about the skills needed for a professional world of uncertainty and change.

Towards the end of the year 2000 the Network was invited to bid for project funding from the Centre for Education in the Built Environment (CEBE) based at Cardiff University (1). This is one of 24 subject-based centres, which comprise the Learning and Teaching Support Network funded by the four UK higher education funding bodies. CEBE will form a key point of contact with five leading disciplines in the built environment (including planning) and will disseminate information and advice on good practice and innovation in learning, teaching and assessment. The Network's contribution will be to focus on the implications for curriculum development and skills teaching in relation to the changing role of planning in the light of the report by the UK Government-sponsored Urban Task Force (1999). The Report particularly highlights the need to promote a closer integration of design and policy-based skills and to encourage inter-disciplinary working between the built environment professions (Urban Task Force 1999: 158).

\section{Note:}

(1) Further information about the Centre for Education in the Built Environment can be found at: http://cebe.cf.ac.uk.

(4546 words) 


\section{References}

Bailey, N. (1998). Into the unknown or into planning? Managing the transition to work in the UK. Journal of Planning Education and Research, vol. 18, pp78-81.

Bailey, N, Butina-Watson, G, Claydon, J, Daniels, I, Higgins, M, MacDonald, K, Morgan, J, Slater, A-M, and Walker, H. (1999). Creativity in Town Planning. London: University of Westminster Press.

Brennan, J \& Little, B. (1996). A Review of Work-based Learning in Higher Education. Sheffield: Department for Education and Employment.

Dearing, R. (1997). Report of the National Committee of Inquiry into Higher Education in the Learning Society. London: National Committee of Inquiry into Higher Education.

Department for Education and Employment. (1998). The Learning Age: a Renaissance for a New Britain. Cmnd. 3790. London: Stationery Office.

Discipline Network in Town Planning. (1996a). Annual Report 1994-95. London: University of Westminster Press.

Discipline Network in Town Planning. (1996b). Report of Survey. London: University of Westminster Press.

Grant, M. (1999). Planning as a Learned Profession. Available on web site: http://www.haynet.com/refer/docs/990115.htm

Hawkins, P \& Winter, J. (1997). Mastering Change: Learning the Lessons of the Enterprise in Higher Education Initiative. Sheffield: Department for Education and Employment.

Higgins, M \& Simpson, F. et al. (1997). Work-based Learning in Planning Education: A good Practice Guide. London: University of Westminster Press.

Higgins, M \& Morgan, J. (2000). The Role of Creativity in Planning: The 'Creative Practitioner'. Planning Practice and Research, 15, pp.117-127.

Urban Task Force. (1999). Towards an Urban Renaissance: Final Report of the Urban Task Force chaired by Lord Rogers of Riverside. London: E\&FN Spon.

McNair, S. (ed.) (1998). Developing Disciplines: The Experience of the Discipline Networks Programme 1995-98. Sheffield: Department for Education and Employment. 